\title{
カントバツクによる鋳鉄の連続分析*
}

\author{
塚 本 昭**.玉 理 博**. 奥山山敬**
}

\section{The Continuous Analysis of Cast Iron by the Quantovac}

\author{
Akira TSUKAMOTO, Hiroshi TAMARI and Kei OKUYAMA
}

(Toyo Kogyo Co., Ltd., Hiroshima)

A study on the excitation conditions and the analytical precision with use of the Shimadzu Vacuum Quantorecorder (or the Quantovac) was made for continuous, rapid and accurate analysis of cast iron, whose Carbon concentration was from 2.80 to $4.20 \%$. It was found that Multisource gave the least variation at $50 \mu \mathrm{H}, 6 \mu \mathrm{F}, 5 \Omega$, and the reproducibility was $1.00 \%$ or less in terms of C.O.V. for each element. Further more, the $\mathrm{Ag}$ counter electrode could be continuously used for more than 750 analyses. Especially, under this condition, the excellent accuracy is easily attained in the routine analytical works which require successive disposal within 2 minutes.

\section{1. 緒言}

カントハミッタによる铸鉄の分析は近尔徐々に实訛さ 机ている。しかし日常分析に拟てカントバック本来の 特徽である速続迅速分析の点ではまだ完全なものではな からた，当社ではキュポラによる䤲鉄の溶解が行なわれ ているため試料起連続的にしかも迅速，正確に分析寸る

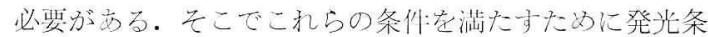
件, 分析精度等種々倹副老加えて所期の目的老達したの で報告手る。

\section{2. 装置と分析線}

装置上分析線を Table 1 に示年.

Table 1. Apparatus and analytical lines

\begin{tabular}{|c|c|c|c|c|c|c|c|c|}
\hline Apparatus & \multicolumn{8}{|c|}{ Shimadzu Vacuum Quantorecorder } \\
\hline \multirow{3}{*}{$\begin{array}{l}\text { Analytical lines } \\
(\AA)\end{array}$} & $\mathrm{Fe}$ & 2714.4 & \multicolumn{2}{|c|}{ internal standard } & $\mathrm{P}$ & 1774.9 & $\mathrm{Cr}$ & 2677.2 \\
\hline & $\mathrm{Mg}$ & 2802.7 & $\mathrm{Si}$ & 2516.1 & $\mathrm{~S}$ & 1807.4 & Mo & 2775.4 \\
\hline & $\mathrm{C}$ & 1930.9 & $\mathrm{Mn}$ & 2933.1 & $\mathrm{Cu}$ & 3274.0 & $\mathrm{Ni}$ & 2316.0 \\
\hline
\end{tabular}

3. 実験方法および実験結果

\section{1 分析試料}

迅速分析家前提としていることから全型急冷試料花採 用しなければならない，そこで種々の金型老考案作彆し て実験 ${ }^{1)}$ し最良の分析精度を与光るもの定求めた。 その

* 炤和 40 年 10 月 日本分光学会秋季满演会厄お いて発表

** 東洋工業株式会社広帛市外府中町

1) 服和 41 年 5 月 日本分光兴会講演会において発 表

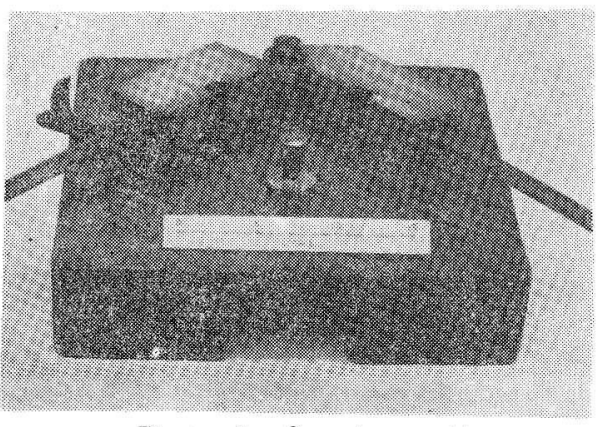

Photo. 1. Sample mould 
Table 2. Composition of the analytical samples

\begin{tabular}{|c|c|c|c|c|c|c|c|c|c|c|}
\hline Elements & $\mathrm{Mg}$ & $\mathrm{C}$ & $\mathrm{Si}$ & $\mathrm{Mn}$ & $\mathrm{P}$ & S & $\mathrm{Cu}$ & $\mathrm{Cr}$ & Mo & $\mathrm{Ni}$ \\
\hline Ranges (\%) & $\begin{array}{c}0.020 \\
? \\
0.070\end{array}$ & $\begin{array}{l}2.80 \\
? \\
4.20\end{array}$ & $\begin{array}{c}1.00 \\
? \\
3.30\end{array}$ & $\begin{array}{c}0.20 \\
? \\
1.20\end{array}$ & $\begin{array}{c}0.020 \\
? \\
0.100\end{array}$ & $\begin{array}{l}0.010 \\
? \\
0.150\end{array}$ & $\begin{array}{c}0.20 \\
? \\
1.00\end{array}$ & $\begin{array}{l}0.10 \\
? \\
1.00\end{array}$ & $\begin{array}{c}0.10 \\
? \\
0.60\end{array}$ & $\begin{array}{l}0.10 \\
? \\
0.40\end{array}$ \\
\hline
\end{tabular}

金型をPhoto. 1 に示す. 金型の材質は FC 25 相当であ る.

分析試料の成分範囲を Table 2 に示す.

\section{2 分析条件}

\section{2.1 発光条件}

キュポラの炉前分析をするため 1 日 200～300 個の試 料を分析しなければならない。

Multisource $50 \mu \mathrm{H} ， 8 \mu \mathrm{F} ， 3 \Omega$ で実験したが，この 条件はある短時間では良い精度が得られるが長時間での 分析值の再現精度が悪い。この原因は主に分析回数と共 に, 対極の先端の幾何学的形状が变わるので, それにと もなつて放電状態が变わるたらと考えられる。約 300 回 で対極を更新しなければならない。乙たがつて対極を更 新するために検量線の移動が生じ，再標準化の時間の口
スが伴う、対極の先端の形状による影響は特にカントバ ックでは重要な C について著しい.

対極を更新すると，放電を安定にするためのならし放 電が 10 分，また全標準試料を放電し検量線を作成する ために約 70 分かかり，合計 80 分全く分析がストップ してしまう.もし 80 分も分析がストップした場合，キ ュポラの溶湯を製品に鋳込むことを中止するか，鋳込ん だにしてもその製品を別にまとめて後程成分のチェック をしなければならないので，キュポラ操業に支障をきた してくる.そこで対極の先端の状態が变わらなければ試 料学連続的に, 迅速, 正確に分析できると考元て対極の 先端が变わりにくい発光条件を探すため, 発光装置の回 路定数を種々变えて実験を行つた. Table 3 に代表例 を示す。

Table 3. Excitation conditions

\begin{tabular}{|c|c|c|c|c|c|c|}
\hline \multicolumn{2}{|c|}{ Excitation conditions } & $\mathrm{L},(\mu \mathrm{H})$ & $\mathrm{C},(\mu \mathrm{F})$ & $\mathrm{R},(\Omega)$ & Primary voltage & $\begin{array}{c}\text { Secondary } \\
\text { voltage }\end{array}$ \\
\hline (A) & \multirow{5}{*}{ Multi Source } & 50 & 8 & 3 & 220 & 1000 \\
\hline (B) & & 50 & 8 & 2.5 & 220 & 1000 \\
\hline (C) & & 50 & 8 & 2 & 220 & 1000 \\
\hline (D) & & 50 & 6 & 5 & 220 & 1000 \\
\hline$(E)$ & & 360 & 8 & 3 & 220 & 1000 \\
\hline$(\mathrm{F})$ & $\mathrm{H} \cdot \mathrm{V} \cdot \mathrm{S}$ & 820 & $0.007 \times 2$ & Residual & 150 & - \\
\hline
\end{tabular}

Multisource $50 \mu \mathrm{H}, 8 \mu \mathrm{F}, 3 \Omega$ は Critical damping の条件故，Unidirectional な放電である上， Sample negative で分析を行なつているのでほとえど試料のみ 隹蒸発して対極は蒸発しない。したがつて対極の先端は Photo. 2 (A) のごとく堆積物ができる.しかし主とし て除極側から蒸発が起こることが知られているから極 㤬劣少し变えてやればこの堆積物它適当に蒸発させて対 極の先端が変化しないようにできる可能性があると考 えて，放電をわずかに振動型にして実験した，放電波形 は $R^{2} \gtreqless 4 L / C$ によつて変化するが, 島津の高性能発光 装置の場合，一香簡単でかつ数多く回路定数を変える事 㕹できるのは，Rであるので，まずこれを $2.18 \Omega \sim 3 \Omega$ まで変えて実験を行なつた。
その代表例が（B)，（C）である.（E）は（A）のL を大きくして振動型としたものであり，（F） は振動型 放電の極端なものの代表として High voltage spark 觉 取り上げ参考とした。(D) は Critical damping の条件 であるが，容量を小さくして試料の蒸発量を抑光，対極 の使用回数を増そうとしたものである。ただ放電ぶ難し くかつ積分洔間が長くなるおそれがある。

また分析間隙も堆積物に有効に働くので，これる 3 $6 \mathrm{~mm}$ の間で変化させ, 分析值の Drift の大きさを調べ た。間陌は大きくなるほど同一発光条件では堆積量が少 ないが放電がむずかしい。しかし我々の試料では Table 3 の条件ではいずれも放電そのものは安定であつたの で，分析閖陌 $6 \mathrm{~mm}$ で実験を行なつた。

使用した試料の成分を Table 4 に示守. 
Table 4. Composition of the test sample

\begin{tabular}{c|c|c|c|c|c|c}
\hline \hline Elements & $\mathrm{Mg}$ & $\mathrm{C}$ & $\mathrm{Si}$ & $\mathrm{Mn}$ & $\mathrm{P}$ & $\mathrm{S}$ \\
\hline $\begin{array}{c}\text { Concentra- } \\
\text { tion (\%) }\end{array}$ & 0.044 & 3.70 & 2.65 & 0.30 & 0.028 & 0.015 \\
\hline
\end{tabular}

実験はつぎのようにして行なつた。すなわち実験装置 は約 8 時間安定化のためのならし運転を行なつた後使用 した。

Table 3 の発光条件の下で，新しい対極をセッテング した後は，全くこれに手を触れる事なく，同一試料を繰 り返し分析し，その 1 回每の記録計上のスペクトル強度 比が分析回数によつてどのように变化するかを調べた。

分析試料の放電面は，3 回分析ごとに研磨をしなおし た. 研磨面が異なるための強度比の変化はみられなから た。なお測光装置の条件を適当に变えて，記録計上のス ペクトル強度比の読みを各条件とも大体同じ程度になる ようにした．対極の先端を毎回ルーペで観察したが，徐 々に变化が大きくなるだけで途中で急激な変化はみられ なかつた.したがつて Photo. 2 に各条件の最終分析回 数における対極の先端の状態だけを示した.ただ（F） だけは最初 4〜6 回までは先端が尖つた状態にあつたが， 以後泻真のごとく丸くなりあまり変化しなかつた。こ の条件だけ毎回分析間陌の調整を行なつた．Fig. 1〜2 の曲線で (D) を除いては, 時々急に強度比が变わつて いるところがあるが，この時の先端の状態もルーペでの

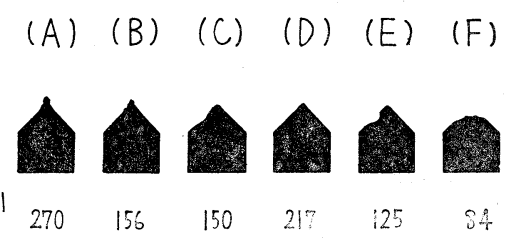

$\begin{array}{lllllll}\text { Analytical } & 270 & 156 & 150 & 217 & 125 & 84\end{array}$

Photo. 2. Profiles of $\mathrm{Ag}$ electrodes after the discharges under the experimented excitation conditions.
観察では変化は特に認められなかつた.しかし (E), (C) での最後の方のカーブのアバレでは対極の消耗が大きく なつていることが認められた。

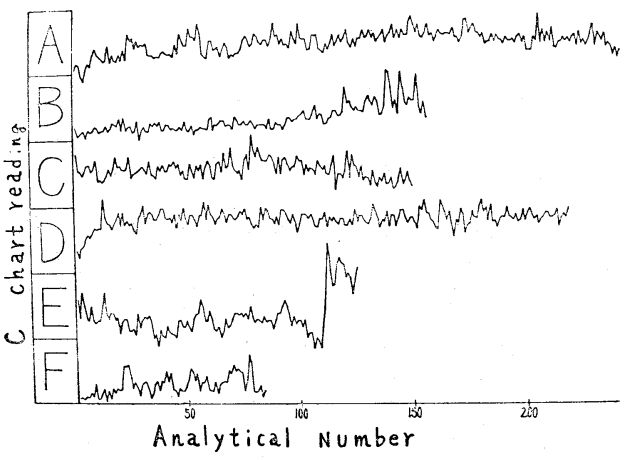

Fig. 1. Carbon chart reading variations in case of successive analyses of the same sample.

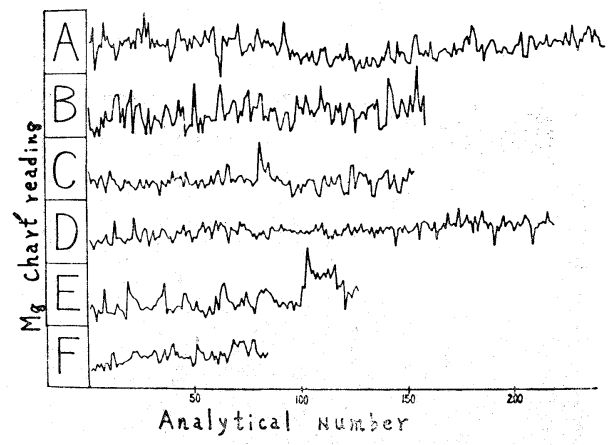

Fig. 2. Magnesium chart reading variations in case of successive analyses of the same sample.

Table 5 は各条件での使用可能であつた最多分析回数 での分析値の再現精度を变動係数で示す。

以上の実験から（D）が対極の先端の状態，再現精度 において最もすぐれている事がわかつた。

Table 5. Coefficients of variation acquired with the experimented excitation conditions

\begin{tabular}{|c|c|c|c|c|c|c|c|c|}
\hline $\begin{array}{l}\text { Excitation } \\
\text { conditions }\end{array}$ & $\begin{array}{l}\text { ments } \\
\text { ical } \\
\text { r }\end{array}$ & $\begin{array}{c}\text { Integral } \\
\text { time } \\
\%\end{array}$ & $\begin{array}{c}\mathrm{Mg} \\
\%\end{array}$ & $\begin{array}{l}\mathrm{C} \\
\%\end{array}$ & $\begin{array}{l}\mathrm{Si} \\
\%\end{array}$ & $\begin{array}{l}\mathrm{Mn} \\
\%\end{array}$ & $\begin{array}{l}\mathrm{P} \\
\%\end{array}$ & $\begin{array}{l}\mathrm{S} \\
\%\end{array}$ \\
\hline (A) & 270 & 1.45 & 4.43 & 1.51 & 1.51 & 2.43 & 3.30 & 6.55 \\
\hline (B) & 156 & 2.00 & 5.20 & 2.63 & 1.04 & 2.68 & 3.85 & 8.33 \\
\hline (C) & 150 & 0.68 & 3.50 & 1.50 & 1.33 & 3.20 & 4.10 & 8.10 \\
\hline (D) & 217 & 0.85 & 3.45 & 0.75 & 1.10 & 1.80 & 2.50 & 5.40 \\
\hline (E) & 215 & 2.58 & 4.10 & 6.92 & 3.10 & 3.10 & 4.50 & 7.30 \\
\hline (F) & 84 & 0.88 & 3.79 & 3.46 & 1.84 & 1.84 & 3.64 & 9.75 \\
\hline
\end{tabular}


なお詨極の1回のセッティング後の分析可能回数は現 在 900 回安越えてな按定である。

Photo. 3 にこの条件の放電波形を, Photo. 4 にこの 条件の下で日常分析作業に执て 750 回分析した後の対 極の先端の状態を示子。

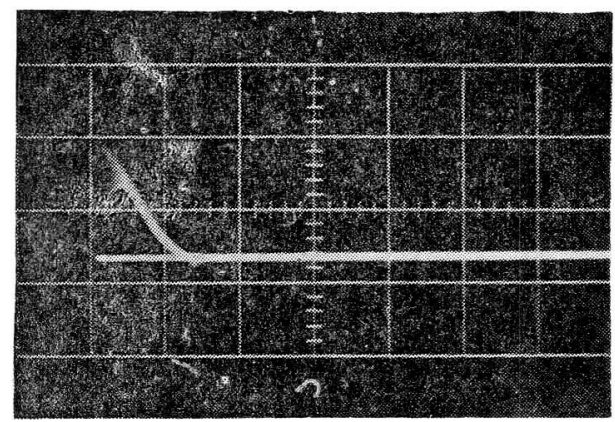

Photo. 3. Oscillogram of Multisource Low voltage spark $50 \mu \mathrm{H}, 6 \mu \mathrm{F}, 5 \Omega$.

(Sweep time $1 \mu \mathrm{sec} / \mathrm{div}$ )

(Diflection sens 5. Volt/div)

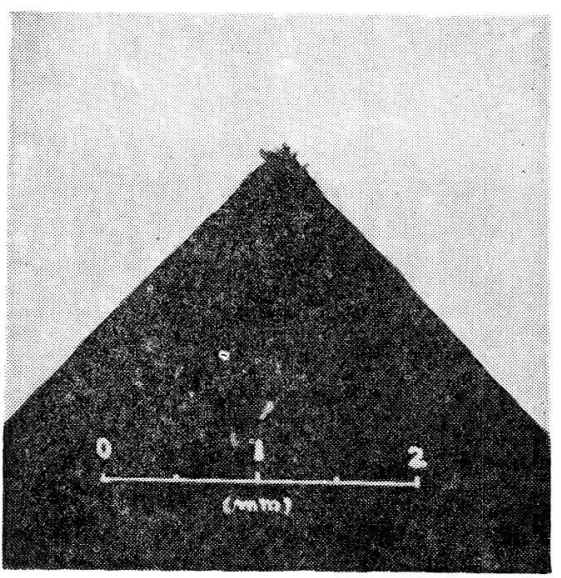

Photo. 4. Profile of $\mathrm{Ag}$ electrode tip after 750 analyses.

\subsection{2 日常分析条件}

最良の分析精度を得るために, 予備放電封間を 5 秒, 20 秒, 40 秒, Ar 流量安 $5 \mathrm{l} / \mathrm{min}, 20 \mathrm{l} / \mathrm{min}, 25 \mathrm{l} / \mathrm{min}$,

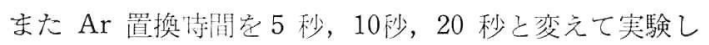
た結果 Table 6 に示专結果が最良であつた.

真空度は $10 \mu \mathrm{Hg}$ 以下では分析值に影響をおよぼさ Table 6. Analytical conditions for the routine work

\begin{tabular}{c|c||c|c}
\hline \hline Prespark & $20 \mathrm{sec}$ & Analytical gap & $6 \mathrm{~mm}$ \\
\hline Ar flush & $10 \mathrm{sec}$ & Vacuum & Below $10 \mu \mathrm{Hg}$ \\
\hline Ar flow & $20 \mathrm{l} / \mathrm{min}$ & Sample polarity & - \\
\hline
\end{tabular}

ないので 1 日約 10 分間真空ポン゚を運転するだけでよ w.

\section{3 標準試料と検量線}

\section{3.1 標準試料}

標準試料は分析試料之同一の治金履歴を持た称ばなら ない。キ土ポラ溶湯より溶解炉每に標準試料学作ること 在検討した。生産工程中では，成分变化が少ないため， 变化の大きい操業の初期と末期充主に敉らつて採取した が，溶湯の温度が低く，また，スラグ等が混入して不均 一な試料となつた。たとえ均一な試料が採取できても濃 度範囲が狭く，各元素々も濃度範囲をもたすためには標 準試料の数が全部で約 50 個になつた。この50 個を同 時に放電すると C だけ溶解炉每に検量線がかかれ，他 元素はだいたい一致した。 50 個安標準試料とすると, 検 量線を作成するだけで約 4 時間以上かかり，実用上問題 がある。

そこで高周波電気炉で配合溶解して作成した。標準試 料の数は 11 個である. 標準試料の数がなお多いのは $\mathrm{Mg}$ が含まれている Group と含まれていない Group にわけたからである. Mg と S は治金学的に相関䦥係 があり， Mg 量を増すと脱硫作用のため残留 $\mathrm{S} \%$ は少 なくなる・

標準試料を放電した結果 C だけ $\mathrm{Mg}$ 有無で検量線が わかれた。その 2 本の検量線は平行であり, 常にその差 は一定である.したがつて検量線の読夕違いをなくし， 検量線の標準化が簡単になるため，Cの検量線は $\mathrm{Mg}$ が含まれていない標準試料を使い，他元素恃全標準試料 を使つている。な肦分析試料と同じ溶解归の標準試料に 近づけるため, チェック用試料, U, V, W はキュポラ 溶解試料を使つている.

この標準試料它使つて多数の試料定分析したところ, C だけ溶解师每にバイアスがあつた。そのバイアスを Table 7 に示卞.

Table 7. Correction constants for $\mathrm{C}$ analysis

\begin{tabular}{c|c|c|c|c}
\hline \hline Samples & S & Z & B & C \\
\cline { 1 - 5 } Correction constants $\%$ & 0.17 & 0.03 & 0.17 & 0.11 \\
\hline
\end{tabular}

S: Ductile cast iron (1) Z: Ductile cast iron (2)

B: Gray cast iron (1) C: Gray cast iron (2)

これは通常の分析範囲では一定であるので，簡単に補 正することができる.

\section{3.2 検 量 線}

検量線の 1 例を Fig. 3， 4 に示亦. 


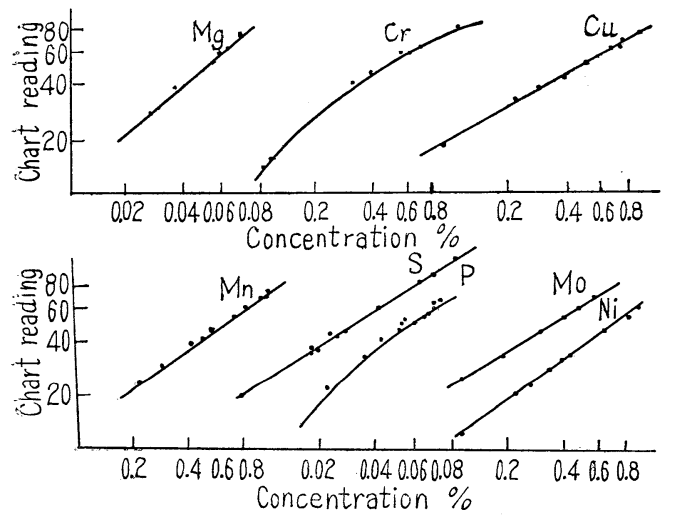

Fig. 3. Working curves.

\section{4 分析 精度}

3. 4.1 再現精度

10回繰句返乙分析の再現精度を Table 8 に示す. 变 動係数注含有量に対する值である.

3. 4.2 正 確 度

キュポラ师前分析時における C の化学分析とカント バック分析との平行分析の結果を Table 9 に示す. 化

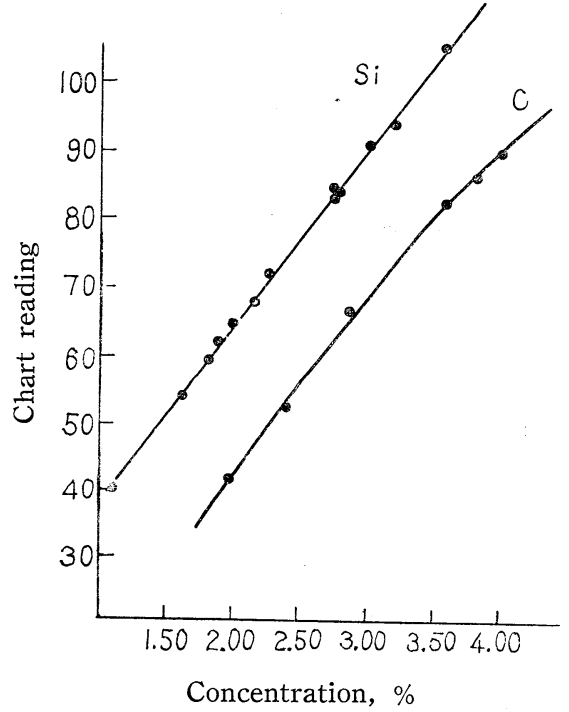

Fig. 4. Working curves.

学分析值はヴェストホッフ社製の電気伝導法による C, $\mathrm{S}$ ，同時定量装置によるものである.

つぎに $\mathrm{Mg}$ のカントバック值と常圧型カントレコー

Table 8. Reproducibility

\begin{tabular}{|c|c|c|c|c|c|c|c|c|c|c|c|}
\hline \multicolumn{2}{|c|}{ Samples Elements } & $\mathrm{Mg}$ & $\mathrm{C}$ & $\mathrm{Si}$ & $\mathrm{Mn}$ & $\mathrm{P}$ & $\mathrm{S}$ & $\mathrm{Cu}$ & $\mathrm{Cr}$ & Mo & $\mathrm{Ni}$ \\
\hline \multirow{2}{*}{$\mathrm{V}$} & Concentration \% & 0.046 & 3.61 & 2.71 & 0.24 & 0.056 & 0.008 & 0.75 & 0.34 & - & - \\
\hline & $\mathrm{COV} \%$ & 1.78 & 0.97 & 0.69 & 1.96 & 1.18 & 0.00 & 1.53 & 1.38 & - & - \\
\hline \multirow{2}{*}{$\mathrm{W}$} & Concentration \% & 一 & 4.00 & 1.99 & 0.31 & 0.067 & 0.025 & 0.81 & 0.40 & 0.48 & 0.26 \\
\hline & $\mathrm{COV} \%$ & - & 1.00 & 0.24 & 0.00 & 0.99 & 1.88 & 1.09 & 1.09 & 0.98 & 0.00 \\
\hline
\end{tabular}

COV: Coefficient of variation

Table 11. Accuracy of all elements

\begin{tabular}{|c|c|c|c|c|c|c|c|c|c|c|c|}
\hline \multicolumn{2}{|c|}{ Samples $\quad$ Elements } & $\mathrm{Mg}$ & $\mathrm{C}$ & $\mathrm{Si}$ & $\mathrm{Mn}$ & $\mathrm{P}$ & $\mathrm{S}$ & $\mathrm{Cu}$ & $\mathrm{Cr}$ & Mo & $\mathrm{Ni}$ \\
\hline \multirow{2}{*}{ S 31} & $\mathrm{CA}$ or $\mathrm{QR}$ & 0.047 & 3.75 & 2.56 & 0.33 & 0.028 & 0.013 & 0.80 & - & - & - \\
\hline & QV & 0.047 & 3.70 & 2.59 & 0.33 & 0.031 & 0.012 & 0.80 & - & 一 & - \\
\hline \multirow{2}{*}{ R 2} & $\mathrm{CA}$ or $\mathrm{QR}$ & - & 3.44 & 1.97 & 0.69 & 0.065 & 0.104 & - & 0.45 & - & - \\
\hline & QV & - & 3.45 & 1.96 & 0.71 & 0.064 & 0.105 & - & 0.43 & - & - \\
\hline \multirow{2}{*}{ D90 } & $\mathrm{CA}$ or $\mathrm{QR}$ & - & 3.71 & 2.57 & 0.69 & 0.031 & 0.031 & 0.23 & 0.94 & 0.40 & 0.23 \\
\hline & QV & - & 3.74 & 2.60 & 0.70 & 0.030 & 0.029 & 0.23 & 0.95 & 0.40 & 0.23 \\
\hline
\end{tabular}

CA: Chemical analysis (C, P, S)

QR: Quantorecorder analysis ( $\mathrm{Mg}, \mathrm{Si}, \mathrm{Mn}, \mathrm{Cu}, \mathrm{Cr}, \mathrm{Mo}, \mathrm{Ni}$ )

$\mathrm{QV}$ : Quantovac analysis 
Table 9. Accuracy of $\mathrm{C}$

\begin{tabular}{|c|c|c|c|c|c|c|c|c|c|c|c|c|c|c|}
\hline $\begin{array}{l}\text { Samp } \\
\text { No. }\end{array}$ & $\mathrm{CA}$ & Q V & $\begin{array}{l}\text { Sample } \\
\text { No. }\end{array}$ & $\mathrm{C} \mathrm{A}$ & $\mathrm{V}$ & $\begin{array}{l}\text { Samp } \\
\text { No }\end{array}$ & $\mathrm{C} \mathrm{A}$ & Q V & $\begin{array}{l}\text { Saml } \\
\text { No }\end{array}$ & $\mathrm{CA}$ & Q V & $\mathrm{am}$ & $\mathrm{A}$ & Q V \\
\hline 1 & & & 1 & & & 3 & & & ( & & & 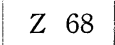 & & \\
\hline S 5 & & & $\begin{array}{ll}Z & 1\end{array}$ & & & $\mathrm{~s}$ & & & Z & & & & 6 & .10 \\
\hline$Z \quad 5$ & 80 & 8 & Z 20 & & & Z 36 & 75 & 6 & & 87 & 96 & & 66 & .68 \\
\hline Z 6 & 77 & 77 & S 21 & & 65 & Z 37 & 74 & 3.73 & $Z 5$ & .75 & 3.7 & & 70 & .09 \\
\hline S 7 & & & Z 2 & & & $Z 3$ & & & Z & 5 & & & 0 & .84 \\
\hline Z 7 & 3.7 & & Z 2 & & & S & & 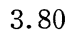 & Z 56 & 75 & 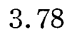 & Z 71 & $y$ & 8 \\
\hline Z 8 & 70 & 68 & Z 23 & .63 & 57 & $Z 3$ & & & $\mathrm{~S}$ & 30 & & & 70 & \\
\hline Z 9 & 67 & & S 2 & & & $Z_{4}$ & & & $Z$ & 0 & 8 & $Z$ & 1 & .59 \\
\hline S 10 & 3.70 & 7 & Z 24 & & 3 & Z 4 & & & $Z$ & 7 & & & & .0 \\
\hline Z 10 & 3.6 & 6 & $Z 2$ & 0 & 3.6 & $Z$ & & & $\mathrm{~S}$ & 2 & & Z & 6 & .69 \\
\hline Z 11 & 3.65 & & S 2 & & & $\mathrm{~S}$ & & & $Z$ & & & & 4 & .00 \\
\hline S 12 & 3.68 & 69 & Z 26 & & & $Z$ & 61 & & $Z 6$ & b & & $Z$ & 5 &. \\
\hline $\begin{array}{ll}Z & 12\end{array}$ & & & Z 27 & & & 3 & 8 & 3.68 & S 60 & 70 & 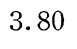 & Z 76 & 75 & .70 \\
\hline Z 13 & & & S 2 & & & Z 4 & & & $Z$ & & & $Z$ & 1 & .70 \\
\hline S 13 & 3 & 3 & Z 28 & & & Z 4 & & & Z 6 & & & & 2 & .80 \\
\hline$Z$ & & & $Z 2$ & & 3.8 & $\mathrm{~S}$ & 0 & 3.72 & Z 63 & 68 & 3.6 & $Z$ & .86 & .78 \\
\hline $\begin{array}{ll}\text { S } 15 \\
\end{array}$ & 3.6 & 3. & Z 30 & & & Z 47 & & & S 64 & & & & 39 & 90 \\
\hline $\begin{array}{ll}Z & 15\end{array}$ & 3.6 & & $Z 3$ & & & $Z$ & & & $Z 6$ & & & $\angle 79$ & 9 & 83 \\
\hline Z & & & S 32 & & & Z 49 & 3 & 3 & $Z 6$ & 5 & 3.6 & $Z \varepsilon$ & 9 & 3. \\
\hline $\begin{array}{ll}\text { S } 17\end{array}$ & 3.52 & J & Z 32 & 3.80 & & Z 50 & & & S 66 & & & 5 & & 04 \\
\hline $\begin{array}{ll}Z & 17\end{array}$ & & & $Z 3$ & & & $Z=$ & & & Z 66 & 57 & 3.66 & Z 81 & 83 & 83 \\
\hline Z & & & & & & Z & 3 & 3.80 & Z 67 & 3.69 & 3.72 & Z 82 & 3.84 & 3.83 \\
\hline
\end{tabular}

CA: Chemical Analysis

QV: Quantovac Analysis

Table 10. Accuracy of $\mathrm{Mg}$

\begin{tabular}{|c|c|c|c|c|c|c|c|c|c|c|c|c|c|c|}
\hline $\begin{array}{l}\text { ample } \\
\text { No. }\end{array}$ & Q R & Q V & & Q R & Q V & & $\mathrm{R}$ & V & & $\mathrm{R}$ & $\mathrm{V}$ & & $2 \mathrm{R}$ & V \\
\hline 2 & 43 & 0.043 & & & & & & & & .044 & & & & \\
\hline$S-2$ & 3 & $5^{\prime \prime}$ & & & & & 043 & 0.044 & -60 & 046 & 0.048 & 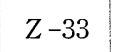 & 044 & 04 \\
\hline & & 7 & & & & & & 45 & & & 48 & $Z-37$ & 45 & 0 \\
\hline & & & & & & & 46 & 45 & $Z-$ & 46 & 48 & & & \\
\hline & & & & & & & 41 & 0.042 & $Z-$ & 049 & 0.051 & & 027 & .02 \\
\hline & & & & & & & & 0.046 & 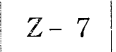 & & 0.048 & & .028 & 0.02 \\
\hline & & & & & & & & & & & 0.046 & & & 0.02 \\
\hline & & & & & & & & 0.042 & & & 0.043 & & & 0.0 \\
\hline & & 50 & $\mathrm{~S}$ & 5 & 44 & & 4 & 0.045 & $Z-1$ & 3 & 0.045 & & .035 & 0.0 \\
\hline & & & & & & & & 47 & & & 0.041 & & 36 & 0.0 \\
\hline & & 843 & & & & & & 0.045 & & & 0.044 & & 0.035 & 0.0 \\
\hline & 42 & 044 & & & & & & 0.047 & & & 0.039 & Z & 0.036 & 0.0 \\
\hline & .045 & 0.046 & & & & & 43 & 0.043 & & & $0.043^{\prime \prime}$ & & 37 & \\
\hline & & & & 4 & 0.0 & & 0.043 & 0.046 & $Z-25$ & 0.045 & 0.043 & $Z-57$ & 0.036 & 0.03 \\
\hline & & & & & & & 0.045 & 0.044 & $Z-$ & 0.044 & 0.044 & $Z-$ & 0.034 & 0.0 \\
\hline $\mathrm{S}-17$ & 045 & 0.048 & 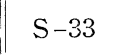 & 044 & 042 & $S-57$ & 046 & 0.046 & & 0.046 & 0.046 & $Z-61$ & 0.033 & 0.0 \\
\hline
\end{tabular}


ダー值との比較を Table 10 に示す、鋳鉄中の $\mathrm{Mg}$ は カントバックによる分析の場合，特買な性質を示音。当 社では $\mathrm{C}, \mathrm{P}, \mathrm{S}$, 以外の分析はすでにカントレコーダー での実績があるのでカントレコーダー值と比較した。

また全元素のカントバック值と化学分析值カントレコ ーダー值との比較の 1 例を Table 11 に示す.

\section{5 検量線の管理}

\subsection{1 管 理 困}

検量線の時間的な移動を的確につか先ために一点管理 図它採用した。Check 用試料を2 時間毎に繰り返し分
析し，その平均值 $\mathrm{X}$ 亿関专る一点管理図を作り，これ によつて検量線の Driftを検出する。をた同時に繰り返 乙3 回の Range ふら通常の $R$ 管理図学作り，これに よつてその時点に京ける分析状態，また Sampleの良否 它判定している。この 2 つの管理図を併用することによ り，カントバック分析自体の正確度（化学分析との比較 ではない.)と再現精度の管理を行なつている。管理限界 は $2 \sigma$ である.C の管理図の 1 例定 Fig. 5 に示す.

また 1 月間の管理限界它 Table 12 に示守。

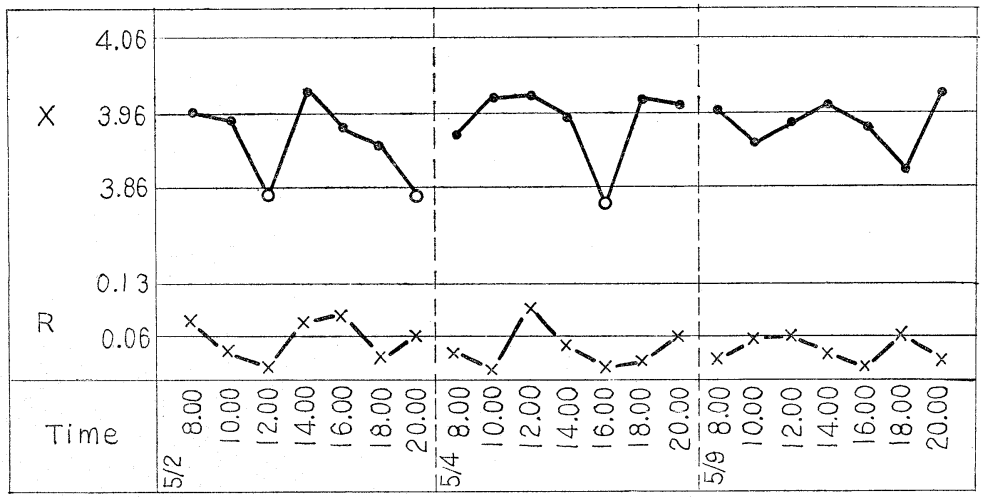

Fig. 5. An example of $X$ and $R$ control chart for $\mathrm{C}$

Table 12. Control limits.

\begin{tabular}{|c|c|c|c|c|c|c|c|c|c|c|c|}
\hline \multirow{2}{*}{\multicolumn{2}{|c|}{ Elements }} & \multicolumn{2}{|c|}{ V } & \multicolumn{2}{|c|}{ W } & & \multirow{2}{*}{ Samples } & \multicolumn{2}{|c|}{$\mathrm{V}$} & \multicolumn{2}{|c|}{ W } \\
\hline & & $\mathrm{X}$ & $\mathrm{R}$ & X & $\mathrm{R}$ & Eleme & & X & $\mathrm{R}$ & $\mathrm{X}$ & $\mathrm{R}$ \\
\hline \multirow{3}{*}{$\mathrm{Mg}$} & UCL & 0.048 & 0.004 & \multirow{3}{*}{ - } & \multirow{3}{*}{ - } & \multirow{3}{*}{$\mathrm{S}$} & UCL & 0.009 & 0.001 & 0.027 & 0.002 \\
\hline & $\mathrm{CL}$ & 0.046 & 0.002 & & & & $\mathrm{CL}$ & 0.008 & 0.000 & 0.026 & 0.001 \\
\hline & LCL & 0.044 & - & & & & LCL & 0.007 & - & 0.025 & - \\
\hline \multirow{3}{*}{$\mathrm{C}$} & UCL & 3.73 & 0.10 & 4.06 & 0.13 & \multirow{3}{*}{$\mathrm{Cu}$} & UCL & 0.78 & 0.04 & 0.84 & 0.03 \\
\hline & $\mathrm{CL}$ & 3.64 & 0.06 & 3.96 & 0.06 & & $\mathrm{CL}$ & 0.76 & 0.02 & 0.82 & 0.02 \\
\hline & LCL & 3.55 & - & 3.86 & - & & LCL & 0.74 & - & 0.80 & - \\
\hline \multirow{3}{*}{$\mathrm{Si}$} & UCL & 2.79 & 0.07 & 2.05 & 0.04 & \multirow{3}{*}{$\mathrm{Cr}$} & UCL & 0.34 & 0.01 & 0.40 & 0.01 \\
\hline & $\mathrm{CL}$ & 2.74 & 0.04 & 2.00 & 0.02 & & $\mathrm{CL}$ & 0.33 & 0.01 & 0.39 & 0.01 \\
\hline & LCL & 2.69 & - & 1.95 & - & & LCL & 0.32 & - & 0.38 & - \\
\hline \multirow{3}{*}{$\mathrm{Mu}$} & $\mathrm{UCL}$ & 0.26 & 0.00 & 0.31 & 0.01 & \multirow{3}{*}{ Mo } & UCL & \multirow{3}{*}{ - } & \multirow{3}{*}{-} & 0.48 & 0.02 \\
\hline & $\mathrm{CL}$ & 0.25 & 0.00 & 0.30 & 0.01 & & $\mathrm{CL}$ & & & 0.47 & 0.01 \\
\hline & LCL & 0.24 & - & 0.29 & - & & LCL & & & 0.46 & - \\
\hline \multirow{3}{*}{$\mathrm{P}$} & $\mathrm{UCL}$ & 0.061 & 0.003 & 0.071 & 0.003 & \multirow{3}{*}{$\mathrm{Ni}$} & UCL & \multirow{3}{*}{-} & \multirow{3}{*}{ - } & 0.26 & 0.01 \\
\hline & $\mathrm{CL}$ & 0.058 & 0.001 & 0.065 & 0.002 & & $\mathrm{CL}$ & & & 0.26 & 0.00 \\
\hline & LCL & 0.055 & - & 0.059 & - & & LCL & & & 0.26 & - \\
\hline
\end{tabular}




\section{5.2 標準化の方法}

2 洔間每にチェック用試料， $\mathrm{V}, \mathrm{W}$, 在それざれ 3 回 繰り返乙分析し，Table 10 の管理恨界内にあれてば，乙 のま分析老続ける。管理际界外の場合はつぎように して，標準化交行なう。C，P，の檢量線は曲線である

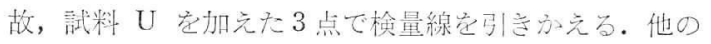
元素の検量線は両刘数万眼医上で平行に移動与るため, $\mathrm{V}, \mathrm{W}, 02$ 点で検量線在引きかえる. (Si 涂く.)

一般に行なわれている. チャンネルの零点, 感度の調 整空する力法は検量線上の 2 点のみのチェックであつ て, しか子その各点は1回分析であり, 检量線管理のた めの分析回数は全部で 2 回である.

我々が採用している方法では 1 点 3 回分析であり，C， P, の分析回数壮 9 回となり, 他元素でも 6 回となる. Fig. 1，Dに示すごとく，Cのドリフトはバラッキに比 ベて非常に小さい.

そこでバッキ在小さくする事が分析精度を向上させ るためにより有効であある。そのた的に分析回数定増 さなければならない.以上のように検量線の管理の正確

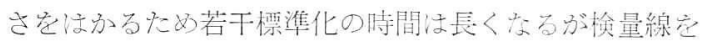
引きかえる力法を採用している。

\section{6 分析工程と分析時間}

\subsection{1 試料研磨}

試料研磨のため社製専用研磨機定使用している。この 研磨機の特徵は試料定一度に平面に研磨与るため, 巾広 の砥石を使用していることである。また試料の研磨，低 石のドレッサー定かける操作が簡単なため, 短时間に, 安全に研磨ができる. その研磨機を. Photo. 5 に示す.

\section{6.2 試料翰送法}

現場よりエヤシュターで $10 \mathrm{~m} / \mathrm{sec} の$ 速さで送られた 試料は分析室の 2 階で研磨され，1階の発光スタンドの,

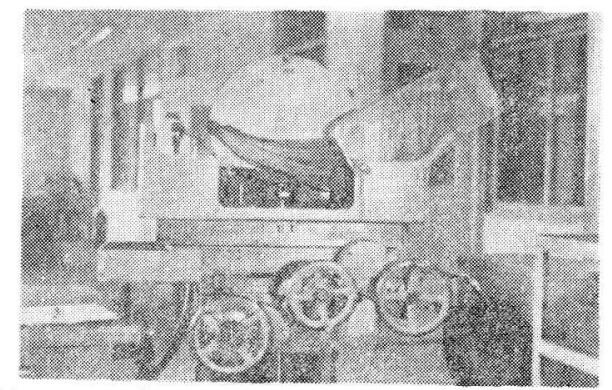

Photo. 5. Specially designed suface grinder for Quantovac Sample.

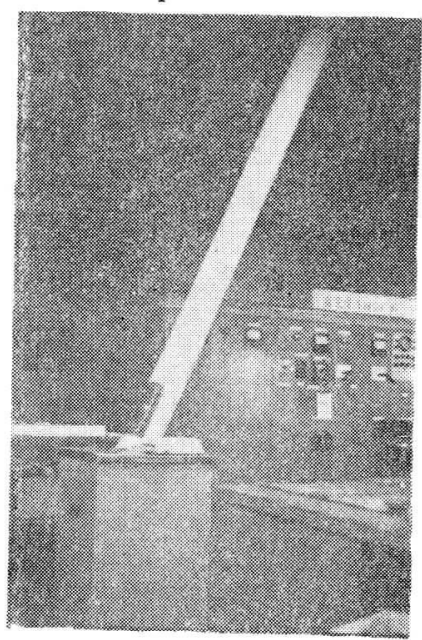

Photo. 6. The sample chute.

Sequence analysis for the continuous analysis

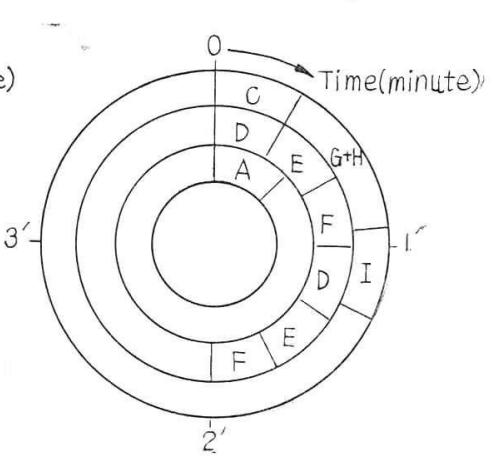
A : Sample preparation
D : Prespark
G: Reading
B : Sample setting
E : Integration
$\mathrm{H}$ : Calculation
C: Ar flush
F : Recording
I : Reporting

Fig. 6. Process and time for analysis. As the sample is analysed with three persons, it takes two minutes for the sample to be analysed in the continuous analysis. 
近くまで Photo. 6 に示す落下筒を通して送られる.

この落下筒を使うことによつて, 試料が簡単に, 短時 間に送られる，また作業者が動かなくてよいため能率的 である。

\subsection{3 結果報告}

分析結果を現場に報告するためにテレメールを使用し ている、これは分析值をペン書きするだけで, 現場にあ る受信機にそのまま伝送されるので, 誰でも直ぐ使え, 誤りがなく，かつ分析結果が保存できる利点がある。

3.6 .4 分析時間

分析工程と分析時間を Fig. 6 に示す. 1 試料 2 回分 析する時間は, 試料到着から結果報告まで, 3 分 50 秒 である。連続的に試料定分析する場合は，各場所で首列 に工程ができるので, 各場所の一番長い時間によつて, 試料を分析できる間隔が決まる. 研磨時間は 30 秒, 発 光時間は 2 分である. 工程中に試料七ット, $\operatorname{Ar}$ 置換時 間がないのは，チャートに記録中にこれらの操作ができ るために，分析時間には含まれない。記録，報告時間は 1 分 15 秒である.したがつて連続的に試料を分析する
場合は 2 分間隔でてきる.

\section{4. 結言}

カントバックによる鋳鉄の連続分析を行なうため, 主 に発光条件, 分析精度について研究し満足な結果を得 た。

（1）発光条件は Multisource $50 \mu \mathrm{H}, 6 \mu \mathrm{F} 5 \Omega$ が最 正良い。

（2）対極は 1 度セッティングした後， 750 放電以上使 用できる。

（3）再現精度は各元素とも変動係数で，1.0\%台また はそれ以下である。

（4）試料を連続的に分析しても，炭素はカントバック 值と化学分析值とがよく一致する.

（5）試料を連続的に分析する場合，2 分間隔で試料を 分析できる。

本報では試料採取方法については触れなかつたが，次 回に発表する予定である. 